\title{
Electrochemical and Quantum Chemical Studies of Adsorption and Corrosion Inhibition of Two New Schiff Bases on Carbon Steel in Hydrochloric Acid Media
}

\author{
Houria Debab ${ }^{1}$, Tahar Douadi ${ }^{1}$, Djamel Daoud ${ }^{1,2, *}$, Saifi Issaadi ${ }^{1}$, Salah Chafaa ${ }^{1}$ \\ ${ }^{1}$ Laboratoire d'Electrochimie des Matériaux Moléculaires et Complexes (LEMMC), Département de \\ Génie des Procèdes, Faculté de Technologie, Université Ferhat ABBAS de Sétif-1, 19000 Sétif, \\ Algeria \\ ${ }^{2}$ Unité de Recherche Appliquée en Energies Renouvelables, URAER, Centre de Développement des \\ Energies Renouvelables, CDER, 47133, Ghardaïa, Algeria \\ *E-mail: daoudkama188@yahoo.fr.
}

doi: $10.20964 / 2018.07 .19$

Received: 23 January 2018 / Accepted: 15 March 2018 / Published: 5 June 2018

The inhibiting effect of two newly synthesized Schiff bases was investigated on the corrosion of carbon steel in $1 \mathrm{M}$ hydrochloric acid solution under various conditions by weight loss, impedance, and potentiodynamic polarization measurements. The Schiff bases used were 4,4'-bis (2-hydroxy-1naphthaldehyde imine) diphenylether (L1) and 4,4'-bis(2-Hydroxy-1-naphthaldéhyde imine) diphenylmethane (L2). The inhibition efficiency of these compounds varied with concentration and immersion time. Potentiodynamic polarization study indicated that the tested compounds are mixed type (cathodic/anodic) inhibitors. Electrochemical impedance spectroscopy was also used to investigate the mechanism of corrosion inhibition, it showed that the charge transfer resistance $\left(R_{\mathrm{ct}}\right)$ increased and double layer capacitance $\left(C_{\mathrm{dl}}\right)$ decreased with an increase in the inhibitor concentration. The inhibition efficiency was found to increase with increasing inhibitor concentration. The adsorption of the inhibitor on the metal surface obeys Langmuir isotherm.

Keywords: Schiff base, Carbon steel, Corrosion inhibitor, EIS, Polarization, DFT.

\section{FULL TEXT}

(C) 2018 The Authors. Published by ESG (www.electrochemsci.org). This article is an open access article distributed under the terms and conditions of the Creative Commons Attribution license (http://creativecommons.org/licenses/by/4.0/). 